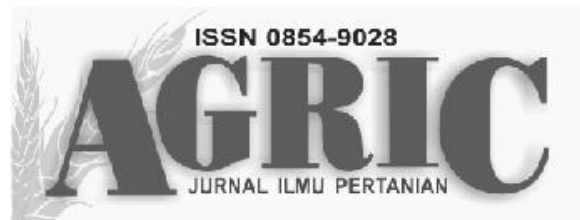

Fakultas Pertanian dan Bisnis Universitas Kristen Satya Wacana Jl. Diponegoro 52-60 SALATIGA 50711 - Telp. 0298-321212 ext 354 email: agric_fpb@yahoo.co.id, website: ejournal.uksw.edu/agric

\title{
DETEKSI KANDUNGAN RHODAMIN B PADA SAUS SERTA CEMARAN BORAKS DAN BAKTERI SALMONELLA SP. PADA CILOK KELILING SALATIGA
}

\section{THE DETECTION OF RHODAMINE B CONTENT ON THE SAUCE AND THE CONTAMINATION OF BORAX AND SALMONELLA SP. IN THE CILOK IN SALATIGA}

\author{
Ardhikajaya Wahyu Prasetya \\ Mahasiswa Fakultas Biologi Universitas Kristen Satya Wacana \\ ardhikajaya3@gmail.com \\ Lusiawati Dewi \\ lusisantoso@yahoo.com \\ Fakultas Biologi Universitas Kristen Satya Wacana
}

Diterima 17 November 2016, disetujui 5 Desember 2016

\begin{abstract}
Borax and rhodamine B are preservative and dye banned to be used in food products. However, some traders still use borax and rhodamine B to their food and drink products. Cilok is a kind of food liked by schoolchildren and categorized as street vendor food (PKL). Most of food sold by street vendor has not touched by strict control from BPOM, so its quality is not good. Pentol cilok is a food made by starch. It tastes delicious and chewy. Furthermore, it is liked by schoolchildren. Cilok is also served by adding the sauce in order to make it tastier. It is common to add dye in that sauce and the dye is not natural dye nor food coloring. In the cilok, the contamination of microbe especially Salmonella sp. is influenced by unhygienic process. This research aims to find out borax and Salmonella sp. contamination and also the existence of rhodamine B on the cilok sauce. The methods used in this research are qualitative, quantitative, and the detection of Salmonella sp. contamination. The result shows, of the 8 tested samples, 4 samples (sample $B, C$, $E$, and $H$ ) contain little amount of borax, the sauce contains no rhodamine B. This can be seen from $R f$ value and color reaction test. On the testing of Salmonella sp., there are bacteria before boiling process (when cilok is still in the form of dough) and there are no bacteria after boiling and steaming process, so it is safe to be consumed.
\end{abstract}

Keywords: Cilok, Borax, Rhodamine B, Salmonella sp. contamination. 


\section{PENDAHULUAN}

Di Indonesia pada umumnya setiap makanan dapat dengan leluasa beredar dan dijual tanpa harus terlebih dahulu melalui kontrol kualitas dan kontrol kesehatan. Salah satu industri yang berkembang secara cepat di Indonesia adalah industri makanan. Dalam industri makanan harus ada faktor kualitas pangan yang dikonsumsi. Menurut UU No. 7 tahun 1996, menyatakan bahwa faktor kualitas pangan yang dikonsumsi harus memenuhi beberapa kriteria, diantaranya adalah aman, bergizi, bermutu dan dapat terjangkau oleh daya beli masyarakat. Aman yang dimaksud mencakup bebas dari pencemaran biologis, mikrobiologi, logam berat dan pencemaran lain yang dapat mengganggu, merugikan dan membahayakan kesehatan manusia (Asteriani $d k k, 2006$ ).

Di dalam pengelolaan makanan selalu diusahakan untuk menghasilkan produk makanan yang disukai dan berkualitas baik. Makanan yang tersaji harus tersedia dalam bentuk dan aroma yang lebih menarik, rasa yang enak, warna dan konsistensinya baik, dan awet. Untuk mendapatkan makanan seperti yang diinginkan, maka pada proses pembuatannya sering dilakukan penambahan "Bahan Tambahan Pangan (BTP)" yang disebut zat aktif kimia (food additive) (Widyaningsih dan Murtini, 2006). Penggunaan Bahan Tambahan Pangan (BTP) harus sesuai dengan aturan perundang-undangan yang telah ditetapkan. Peran bahan tambahan pangan (BTP) khususnya bahan pengawet menjadi semakin penting sejalan dengan kemajuan teknologi produksi bahan tambahan pangan sintetis. Bahan pengawet umumnya digunakan untuk mengawetkan pangan yang sifatnya mudah rusak (Cahyadi, 2008).

Bahan pengawet yang sering digunakan di Indonesia yaitu boraks. Boraks adalah senyawa berbentuk kristal, warna putih, tidak berbau dan stabil pada suhu tekanan normal dan bersifat sangat beracun, sehingga peraturan pangan tidak memperbolehkan penggunaan boraks dalam pangan. Banyak orang yang belum mengetahui bahaya borak pada makanan yang sering kita konsumsi sehari-hari yang dapat menimbulkan dampak buruk, bahkan jika digunakan dalam waktu yang lama dapat menimbulkan kematian. Masyarakat sekarang ini hanya mengetahui bahwa makanan yang dibelinya enak dan harganya murah tanpa mengetahui kandungan zat-zat berbahaya yang ada di dalamnya (Winarno, 1994). Penggunaan bahan tambahan pangan khususnya boraks perlu diwaspadai oleh produsen maupun konsumen. Seseorang yang mengkonsumsi makanan yang mengandung boraks tidak akan langsung mengalami dampak buruk bagi kesehatan, tetapi senyawa tersebut diserap dalam tubuh secara kumulatif. Selain melalui saluran pencernaan, boraks dapat diserap melalui kulit. Dosis yang cukup tinggi dalam tubuh akan menyebabkan munculnya gejala pusing, muntah dan kram perut. Pada anak kecil dan bayi, bila dosis dalam tubuhnya sebanyak 5 gram atau lebih dapat menyebabkan kematian, sedangkan untuk orang dewasa kematian terjadi pada dosis 10 sampai 20 gram (Purnomo, 1998).

Cilok adalah makanan ringan menyerupai pentol (bulatan) yang terbuat dari tepung kanji, berasa gurih dan kenyal. Awalnya makanan ini merupakan makanan khas dari Jawa Barat, namun sekarang sudah mulai merambah ke daerahdaerah lain. Akses yang mudah serta banyaknya peminat membuat para pedagang ramai-ramai menggunakan bahan tambahan pangan mulai dari yang alami hingga bahan kimia yang dilarang penggunaannya seperti boraks. Hal ini bertujuan untuk mencegah cilok menjadi rusak dan cepat basi. Pemerintah telah melarang penggunaan boraks sebagai bahan tambahan makanan melalui Peraturan Menteri Kesehatan RI No.772/ Menkes/Per/IX/88 dan No.1168/Menkes/Per/X/ 
1999 (Cahyadi, 2008). Cilok tergolong dalam kategori makanan pedagang kaki lima (PKL). Makanan PKL belum tersentuh pengawasan yang ketat oleh BPOM sehingga secara kualitas tidak terpantau dengan baik.

Dalam penyajiannya, cilok diberi saus tomat yang akan memberi cita rasa. Akan tetapi ternyata masih ada produsen yang sengaja menambahkan zat warna rhodamin B untuk produk cabe giling dan saus sebagai pewarna merah dengan alasan warnanya sangat bagus, mudah didapat, dan murah harganya. Sebagian besar produk tersebut tidak mencantumkan kode, label, merek, jenis atau data lainnya yang berhubungan dengan zat warna tersebut. Para pedagang cabe merah giling menggunakan pewarna untuk memperbaiki warna merah cabe giling yang berkurang (menjadi pudar) akibat penambahan bahan campuran seperti wortel dan kulit bawang putih. Rhodamin B merupakan zat warna sintetik yang umum digunakan sebagai pewarna tekstil. Menurut Peraturan Pemerintah RI No. 28, Tahun 2004, rhodamin B merupakan zat warna tambahan yang dilarang penggunaannya dalam produk-produk pangan (SNI, 2004). Rhodamin B dapat menyebabkan iritasi saluran pernafasan, iritasi kulit, iritasi pada mata, iritasi pada saluran pencernaan, keracunan, dan gangguan hati. Akan tetapi sampai sekarang kemungkinan masih ada produsen yang menggunakan rhodamin B dalam produk makanan dan minuman yang dihasilkannya (Lee, 1989).

Selain itu, perlu diwaspadai akan kemanan pangan dari cilok tersebut, karena biasanya cilok dijual dalam keadaan terbuka dan dibiarkan dalam waktu yang lama, sehingga memungkinkan terjadinya cemaran oleh mikroba. Cemaran oleh mikroba pada cilok juga dipengaruhi oleh sanitasi selama proses pengolahan serta higienis dari penjamah makanan. Dalam proses pembuatan cilok, bisa jadi terkontaminasi bakteri saat proses pembuatan ataupun saat pemasaran.
Adanya kontaminasi bakteri dapat menyebabkan penyakit terutama yang disebabkan oleh Salmonella sp. Bakteri ini sering dijadikan standar utama kebersihan pangan, karena mengindikasikan adanya cemaran-cemaran bakteri lain yang berpotensi menyebabkan penyakit (Odonkor $d k k$., 2013). Salmonella sp. dalam jumlah yang berlebih dapat membahayakan konsumen karena dapat menimbulkan infeksi terutama pada cilok yang diedarkan di sekolah maupun tempat-tempat umum. Jumlah yang berlebih dari Salmonella sp. bisa jadi menunjukkan kurangnya kebersihan dan tingkat keamanan pangan yang rendah akibat adanya kontaminasi dalam bahan atau proses yang dilakukan ketika produksi (Mansauda $d k k$., 2014). Penelitian ini dilakukan dengan tujuan untuk mengidentifikasi dan menganalisis cemaran boraks dan cemaran bakteri Salmonella $s p$. pada cilok keliling di Kota Salatiga serta keberadaan rhodamin B pada saus cilok.

\section{METODE PENELITIAN}

\section{Waktu dan Tempat Penelitian}

Penelitian dilakukan pada bulan September sampai November 2016, bertempat di Laboratorium Mikrobiologi dan Laboratorium Biokimia dan Biologi Sel Molekuler, Fakultas Biologi, Universitas Kristen Satya Wacana, Salatiga.

\section{Alat dan Bahan}

Alat-alat yang digunakan dalam melakukan penelitian diantaranya adalah alat ukur gelas, timbangan analitik, kertas kromatografi, spatula, inkas, buret, statif, inkubator, vortex, hot plate and stirrer, dan autoclave.

Bahan-bahan yang digunakan dalam melakukan penelitian yaitu sampel cilok dan saus, bleng, kunyit, $\mathrm{NaOH} 0,1 \mathrm{M}$, air garam, larutan methanol, $\mathrm{NaOH} 10 \%$, HCL $10 \%$, HCL pekat 37\%, larutan garam fisiologis, manitol 0,2 gram, kertas saring, 
fenolftalein, $\mathrm{NH}_{4} \mathrm{OH} 10 \%, \mathrm{H}_{2} \mathrm{SO}_{4}$ pekat, medium Salmonella Shigella Agar (SSA) dan akuades.

\section{Pengambilan Sampel}

Sampel diambil secara acak di delapan lokasi sekolah yang berbeda-beda. Lokasi sampel ditentukan berdasarkan tersedianya penjual cilok keliling yang sering bertempat di Sekolahsekolah Dasar dan Menengah di Salatiga. Sampel cilok diambil untuk dideteksi ada tidaknya boraks, rhodamin B dan Salmonella sp.

\section{Uji Kandungan Boraks}

\section{Analisis Kualitatif}

a. Uji nyala

Sampel cilok dipotong kecil-kecil dan dimasukkan ke dalam cawan porselen. Sampel kemudian ditetesi dengan larutan methanol dan didiamkan beberapa saat. Sampel dibakar dengan korek api dan diamati nyala apinya. Jika nyala api berwarna hijau, maka sampel cilok positif mengandung boraks.

\section{b. Uji Tumerik}

Kunyit segar diparut dan disaring airnya. Kemudian kertas saring dicelupkan ke air kunyit tersebut dan dibolak-balikkan hingga merata setelah itu dikeringkan. Sampel cilok ditumbuk hingga halus lalu ditambahkan akuades dengan perbandingan 1:1.Setelah itu disaring dan diambil filtratnya. Filtrat tersebut diteteskan pada kertas tumerik yang sudah dikeringkan dan diamati perubahan warnanya. Sebagai kontrol positif (adanya boraks), 1 sendok bleng dilarutkan ke dalam air lalu diteteskan ke kertas tumerik tersebut (berubah menjadi merah jingga).

\section{Analisis Kuantitatif}

Sebanyak 10 gram sampel diabukan hingga kering lalu diberi akuades. Kemudian disaring untuk diambil filtratnya. Sebanyak $15 \mathrm{ml}$ filtrat dimasukkan ke dalam erlenmeyer kemudian ditambahkan HCL pekat 37\% dan 0,2 gram manitol. Selanjutnya diberi 2 tetes indikator fenolftalein dan dititrasikan dengan $\mathrm{NaOH} 0,1$ M. Perubahan warna diamati hingga warna berubah menjadi merah muda dan dicatat volume yang dibutuhkan. Setelah itu dihitung kadar boraksnya (Herlich, 1990).

\section{Uji Kandungan Rhodamin B}

\section{Uji Dugaan Rhodamin B}

Sampel yang telah diencerkan diambil sebanyak $\pm 20 \mathrm{ml}$ kemudian ditambahkan larutan $\mathrm{HCl} 10 \% \pm 0,5 \mathrm{ml}$ sampai kondisi asam. Kemudian ditambahkan benang wool $( \pm 20 \mathrm{~cm})$ dan dipanaskan sampai mendidih selama 20 menit. Kemudian benang wool diambil dan dicuci sampai bersih. Setelah itu, benang wool dipotong menjadi 4 bagian. Tiap potongan ditetesi $\mathrm{NaOH} 10 \%, \mathrm{HCl}$ pekat, $\mathrm{H}_{2} \mathrm{SO}_{4}$ pekat dan $\mathrm{NH}_{4} \mathrm{OH} 10 \%$. Apabila mengandung rhodamin B maka warna akan berubah menjadi jingga ( $\mathrm{HCl}$ pekat), kuning $\left(\mathrm{H}_{2} \mathrm{SO}_{4}\right.$ pekat), biru $(\mathrm{NaOH}$ $10 \%)$ dan biru $\left(\mathrm{NH}_{4} \mathrm{OH} 10 \%\right)$.

\section{Uji Penegasan Rhodamin B}

Air hangat dimasukan ke dalam gelas, kemudian dicampur dengan garam secukupnya (tidak berlebih) dan diaduk. Air hangat yang bercampur dengan garam didiamkan sampai dingin. Digunting kertas kromatografi, kemudian digaris dengan pensil setelah itu diberi setitik sampel ditengah-tengah kertas sejajar dengan garis pensil. Kemudian setelah air yang bercampur garam dingin, kertas kromatografi yang ditetesi sampel tersebut dimasukan ke dalam air dengan batas garis di atas air (garis tidak terkena air).

\section{Deteksi Cemaran Salmonella sp.}

Sampel cilok ditumbuk halus lalu dimasukkan ke dalam garam fisiologis. Larutan suspensi diambil sebanyak $0,2 \mathrm{ml}$ dengan pengulangan 3 
kali. Kemudian, larutan suspensi tersebut ditaburkan pada permukaan medium spesifik Salmonella Shigella Agar (SSA) dan diratakan menggunakan batang L (drigalski) steril. Setiap akan meratakan larutan suspensi yang ditabur, batang L harus dicelupkan ke dalam alkohol 96\%, kemudian dibakar dengan bunsen, dan ditunggu beberapa saat hingga batang L tidak terlalu panas. Setelah seri pengeceran diinokulasikan pada medium SSA, medium diinkubasi pada suhu $37^{\circ} \mathrm{C}$ selama 24-48 jam. Deteksi cemaran bakteri Salmonella sp. dilihat dari ada (+) atau tidak ada (-) pertumbuhan bakteri tersebut pada medium spesifik. Jika tumbuh koloni yang diduga Salmonella sp., koloni tersebut tidak akan berwarna (colorless) dengan inti hitam besar di tengah (Narumi $d k k ., 2009$ ).

\section{Analisis Data}

Data yang diperoleh akan dianalisis menggunakan analisis deskriptif dengan perlakuan 8 sampel dan ulangan tiga kali. Data yang sudah diolah kemudian dinilai kuantitas kandungan boraks, kualitas rhodamin B ada atau tidaknya Salmonella sp., serta disajikan dalam bentuk tabel, narasi dan deskriptif.

\section{HASIL DAN PEMBAHASAN}

\section{Uji Kandungan Boraks}

Hasil dari uji nyala dan uji tumerik pada delapan sampel yang diteliti dengan metode tersebut dari seluruh kecamatan di Salatiga semuanya tidak terlihat adanya boraks. Oleh karena itu, pengujian dilanjutkan dengan uji kuantitatif dengan metode titrasi untuk mendeteksi kadar kandungan boraks. Sampel A-H diambil dari pedagang yang sering berjualan di sekolah-sekolah tersebut. Berikut ini daftar sekolah yang diambil sampelnya:

Sampel A : SDN 03/10 Salatiga;

sampel B : SDN Kauman Kidul;

sampel C : SDN LEDOK 02; sampel D : SDN Noborejo 01;

sampel E : SDN Mangunsari 05;

sampel F : SDN Kutowinangun 01;

sampel G : SDN Dukuh 01;

sampel H : SDN Kalibening

Tabel 1 Hasil Uji Nyala dan Tumerik Kandungan Boraks pada Cilok

\begin{tabular}{ccc}
\hline Sampel & Uji Nyala & Uji Tumerik \\
\hline A & Kuning & Warna kuning (-) \\
B & Kuning & Warna kuning (-) \\
C & Kuning & Warna kuning (-) \\
D & Kuning & Warna kuning (-) \\
E & Kuning & Warna kuning (-) \\
F & Kuning & Warna kuning (-) \\
G & Kuning & Warna kuning (-) \\
H & Kuning & Warna kuning (-) \\
Bleng (Kontrol) & Hijau & Warna merah kecoklatan \\
& & $(+)$ \\
\hline
\end{tabular}

Keterangan: - : tidak mengandung boraks

$+:$ mengandung boraks

Dari tabel 2 di bawah ini dapat dilihat bahwa terdapat 4 sampel yang mengandung kadar boraks. Yaitu sampel B (0,22 ppm), sampel C (0,14 ppm), sampel E (0,29 ppm) dan sampel H $(0,09 \mathrm{ppm})$.

Tabel 2 Analisis Kadar Kandungan Boraks yang Diperiksa

\begin{tabular}{cc}
\hline Sampel & $\begin{array}{c}\text { Kadar Boraks } \\
(\mathrm{ppm})\end{array}$ \\
\hline B & 0,22 \\
C & 0,14 \\
E & 0,29 \\
H & 0,09 \\
\hline
\end{tabular}

Uji kualitatif pada Tabel 1 tidak terlalu terlihat terutama uji tumerik, hal ini dikarenakan kunyit hanya dapat mendeteksi minimal 200 ppm boraks begitu juga dengan uji nyala. Sedangkan dari hasil analisis kuantitatif yang diujikan terdapat 4 sampel yang mengandung sedikit boraks (di bawah 200 ppm). Jika ikatan yang terjadi antara kurkumin dengan asam borat kurang kuat, maka senyawa rososianin yang menghasilkan warna 
merah kecoklatan dari reaksi tersebut tidak terbentuk. Oleh sebab itu pengujian kualitatif yang terlihat pada tidak menghasilkan warna merah kecoklatan pada uji tumerik tersebut. Kebutuhan Boron untuk orang dewasa adalah 1-2 mg/ hari (Bellittz dkk, 2009). Dosis fatal penggunaan boraks adalah 5-20 g/hari (Badan POM, 2002). Sedangkan menurut standar internasional dosis fatal boraks berkisar 3-6 g/ hari untuk bayi dan anak kecil, untuk orang dewasa sebanyak 15-20 g/hari (Litovitz et al., 1998 dalam WHO, 1998). Dalam jumlah banyak boraks menyebabkan demam, anuria, koma, kerusakan sistem saraf pusat, sianosis, kerusakan ginjal, anemia, muntah, diare, pingsan (Devirian dan Volpe, 2003). Dari penelitian See (2010) melaporkan bahwa asam borat yang merupakan kandungan dari boraks dapat merusak epithelium spermagonia dengan menghambat pembentukan DNA pada sel sperma.

Penggunaan boraks dalam pembuatan makanan jajanan bertujuan untuk mengawetkan makanan, karena efektif melawan ragi dan bakteri yang menyebabkan kerusakan pada makanan. Selain itu dapat meningkatkan kekenyalan pada makanan sehingga terasa enak dimakan (Janny, 2009). Pada umumnya konsumen akan mencari makanan yang kenyal daripada yang lembek dan mudah hancur. Cilok merupakan jenis makanan basah, menurut penelitian Fitri Eka Lestari, 2009, kandungan air cilok yaitu $41 \%$. Jenis-jenis makanan yang kandungan airnya tinggi mudah mengalami kerusakan. Oleh karena itu perlu diberi bahan pengawet. Bahan pengawet yang biasa digunakan adalah boraks. Penggunaan boraks pada makanan masih diperbolehkan dengan ketentuan tidak melebihi Acceptable Daily Intake (ADI). Untuk boraks menurut European Food Safety Authority (EFSA 2004) sebanyak 0,16mg/kgBB/hari (EBA, 2010).

Secara umum, boraks diabsorbsi lebih dari $90 \%$ dari dosis yang diberikan melalui oral. Dalam makanan, boraks akan terserap oleh darah dan disimpan dalam hati. Boraks didistribusikan dalam jaringan tubuh dan dieliminasi melalui urin selama kurang lebih 13 jam. Dibutuhkan energi $523 \mathrm{~kJ} / \mathrm{mol}$ atau setara dengan $125.520 \mathrm{kcal} /$ mol untuk memecah komponen boraks agar dapat dimetabolisme oleh tubuh atau dibutuhkan energi sebesar 329,12 kcal/gram boraks. Karena tidak mudah larut dalam air dan tingginya energi yang dibutuhkan untuk memecah komponen boraks, sehingga boraks tersebut bersifat kumulatif di dalam tubuh (USDA, 2006). Sisa zat kimia yang tidak bisa terurai akan terakumulasi sebagai bahan tidak bermanfaat yang bersifat racun (Saparinto dan Hidayati, 2006).

\section{Uji Kandungan Rhodamin B pada Saus Cilok}

Pada uji kandungan rhodamin B, menggunakan uji reaksi warna dan kromatografi kertas untuk melihat rhodamin B pada saus cilok. Sampel A, B, F dan G pada reaksi warna diuji dengan pereaksi $\mathrm{HCl}$ pekat tidak mengalami perubahan warna, begitu juga dengan penambahan pereaksi seperti $\mathrm{H}_{2} \mathrm{SO}_{4}$ pekat, $\mathrm{NaOH} 10 \%$, dan $\mathrm{NH}_{4} \mathrm{OH}$ $10 \%$ saus tidak mengalami perubahan warna. Dari reaksi warna tersebut dapat ditarik kesimpulan bahwa sampel tidak terdeteksi mengandung pewarna Rhodamin B. Sampel C dan $\mathrm{E}$ hanya berubah warna menjadi merah muda $\left(\mathrm{H}_{2} \mathrm{SO}_{4}\right.$ pekat) dan untuk sampel D saat direaksikan dengan $\mathrm{H}_{2} \mathrm{SO}_{4}$ pekat dan $\mathrm{HCl}$ pekat maka juga berubah menjadi merah muda. Akan tetapi kedua sampel tersebut juga tidak mengandung rhodamin $\mathrm{B}$.

Pada uji reaksi warna yang terdapat pada Tabel 3 , semua sampel yang direaksikan tidak menunjukkan kandungan rhodamin B. hal ini dapat dilihat dari keterangan warna yang disajikan pada tabel tersebut. Untuk grafik 1 di atas dapat dilihat bahwa terdapat beda nyata antara kontrol (rhodamin B) dengan sampel A-H. Hal ini mem- 
buktikan bahwa saus yang digunakan pedagang tidak menggunakan pewarna rhodamin B.

Hasil penelitian ini menunjukkan bahwa saus cilok tusuk yang dijual oleh pedagang tidak mengandung zat pewarna yang dilarang oleh pemerintah. Berdasarkan wawancara langsung dengan para pedagang, pedagang membeli saus di toko lalu ditambahkan dengan garam, vetsin, bawang merah, dan bawang putih kemudian dicampur dengan air masak, tetapi ada juga pedagang yang membuat/meracik sendiri saus tersebut. Pedagang mulai menyadari bahwa penggunaan rhodamin $\mathrm{b}$ pada makanan dalam waktu yang lama dapat mengakibatkan gangguan fungsi hati maupun kanker (Yuliarti, 2007). Pedagang yang berjualan menyajikan saus ber- beda-beda, ada yang berwarna merah mencolok dan ada juga yang menyajikan saus cilok tusuk dengan warna merah pudar. Para pedagang umumnya menggunakan ubi merah yang dihaluskan kemudian ditambahkan maizena sehingga menjadi kental. Warna merah mencolok pada saus dan makanan jajanan lain yang dijual oleh pedagang, bukan berarti semua mengandung zat pewarna berbahaya yang dilarang oleh pemerintah yaitu rhodamin B. Akan tetapi, walaupun tidak semua makanan jajanan dan saus tomat yang warnanya merah mencolok tidak mengandung rhodamin B. Masyarakat lebih khususnya anak-anak yang sering jajan sembarangan perlu adanya sikap kehati-hatian dalam mengkonsumsi makanan jajanan yang dibeli.

Tabel 3 Hasil Analisis Rhodamin B Saus Cilok

\begin{tabular}{ccccccc}
\hline Sampel & $\begin{array}{c}\mathrm{NaOH} \\
10 \%\end{array}$ & $\mathrm{NH}_{4} \mathrm{OH} \mathrm{10 \%}$ & $\mathrm{H}_{2} \mathrm{SO}_{4}$ Pekat & HCL Pekat & Nilai Rf & Kesimpulan \\
\hline Rhodamin B & Biru & Biru & Kuning & Jingga & 0,68 & Positif (+) \\
Saus A & Bening & Bening & Bening & Bening & 0,38 & Negatif (-) \\
Saus B & Bening & Bening & Bening & Bening & 0,40 & Negatif (-) \\
Saus C & Bening & Bening & Merah muda & Bening & 0,43 & Negatif (-) \\
Saus D & Bening & Bening & Merah muda & Merah muda & 0,26 & Negatif (-) \\
Saus E & Bening & Bening & Merah muda & Bening & 0,41 & Negatif (-) \\
Saus F & Bening & Bening & Bening & Kuning & 0,29 & Negatif (-) \\
Saus G & Bening & Bening & Bening & Kuning & 0,24 & Negatif (-) \\
Saus H & Bening & Merah Muda & Merah Muda & Bening & 0,32 & Negatif (-) \\
\hline
\end{tabular}

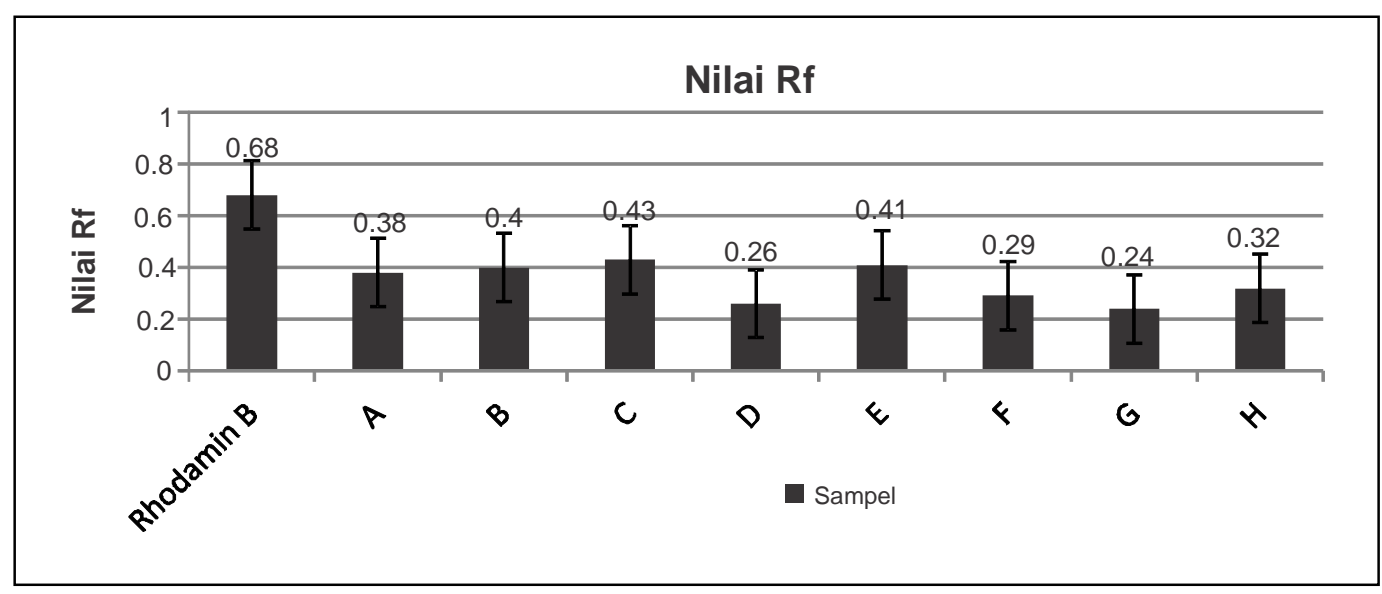

Grafik 1 Nilai Rf Pada Sampel 
Tabel 4 Hasil Deteksi Bakteri Salmonella sp. dari Sampel Cilok pada Medium SSA.

\begin{tabular}{cccccccc}
\hline \multirow{2}{*}{ No } & \multirow{2}{*}{ Sampel } & \multicolumn{3}{c}{ Sebelum Direbus } & \multicolumn{3}{c}{ Setelah Direbus } \\
\cline { 3 - 7 } & A & U1 & $\mathbf{U}^{2}$ & $\mathbf{U}_{3}$ & $\mathbf{U} 1$ & $\mathbf{U}_{2}$ & $\mathbf{U}^{3}$ \\
\hline 1 & $\mathrm{~B}$ & + & + & + & - & - & - \\
2 & $\mathrm{C}$ & + & + & - & - & - & - \\
3 & $\mathrm{D}$ & + & + & - & - & - & - \\
4 & $\mathrm{E}$ & + & - & - & - & - & - \\
5 & $\mathrm{~F}$ & + & + & - & - & - & - \\
6 & $\mathrm{G}$ & + & - & - & - & - & - \\
7 & $\mathrm{H}$ & + & - & - & - & - & - \\
8 & & + & + & - & - & - \\
\hline Keterangan: +: positif ada Salmonella sp. & $-:$ negatif tidak ada Salmenella sp.
\end{tabular}

Berdasarkan hasil di atas, tidak ditemukan jenis bakteri Salmonella sp. pada jajanan cilok yang dijual di sekitar lingkungan SD. Bakteri Salmonella $s p$ merupakan bakteri yang biasa mengontaminasi makanan, bakteri ini tumbuh optimal pada suhu $37^{\circ} \mathrm{C}$. Keberadaan bakteri ini pada makanan dapat disebabkan oleh penjamah/pengolah yang kurang higienis serta peralatan yang kurang higienis pula. Bakteri ini dapat mengontaminasi makanan baik saat selama pengolahan maupun saat makanan sudah matang karena proses perebusan memakai suhu $\pm 100^{\circ} \mathrm{C}$ (Matuwo, 2012). namun bisa saja bakteri dapat mengontaminasi lagi setelah makanan tersebut matang. Hal ini dapat dikarenakan peralatan yang digunakan untuk menyentuh makanan matang kurang bersih, terkena debu, kontak dengan udara kotor, terbawa oleh serangga (lalat dan kecoa) maupun kurang benar dalam menyimpan makanan (Delost, 2005). Dari uji sampel yang dilakukan dalam penelitian tidak ditemukan adanya bakteri Salmonella sp. yang mengkontaminasi jajanan cilok yang siap dikonsumsi. Menurut Budiono dkk (2012), adanya cemaran Salmonella sp., tidak selalu akan menimbulkan perubahan warna, rasa, dan aroma pada makanan. Dosis infeksi Salmonella sp. adalah sebesar $10^{7}-10^{9}$ per gram sampel (Antara dkk, 2008).
Walaupun pada penelitian Salmonella sp. yang terdeteksi sedikit, namun tetap berpotensi menyebabkan penyakit karena bakteri tersebut akan berkembang apalagi lingkungan pedagang yang kurang bersih. Pada sampel tidak terdapat kontaminasi bakteri Salmonella sp. karena bakteri tersebut sudah mati pada saat proses pemanasan dengan suhu tinggi sehingga bakteri tidak dapat tumbuh. Dari tabel 4 dapat dipastikan bahwa cilok aman dikonsumsi karena sudah melewati perebusan dan pengukusan yang menyebabkan kuman dan bakteri mati. Pedagang kaki lima sekarang ini sudah memperhatikan kebersihan, termasuk menyajikan cilok dengan wadah dalam kondisi tertutup. Selain itu, pedagang juga menyimpan cilok pada risopan yang selalu dipanaskan guna menghindari kontaminan bakteri. Apabila wadah dibiarkan terbuka sangat memungkinkan pertumbuhan mikroba patogen, seperti parasit dan bakteri. Karena kontaminasi makanan oleh mikroba patogen dapat menyebabkan gangguan-gangguan kesehatan pada konsumen. Untuk mengurangi resiko infeksi penyakit bagi konsumen, maka perlu diperhatikan beberapa hal antara lain sanitasi dan higiene makanan serta penyimpanan makanan secara tepat dan benar. 


\section{KESIMPULAN}

Semua sampel cilok pada uji kualitatif tidak terlihat adanya boraks, akan tetapi saat diuji kuantitatifnya terdapat 4 sampel yang mengandung sedikit boraks. Selain itu saus yang dipakai juga tidak terdapat rhodamin B karena pedagang pada umumnya menggunakan bahan-bahan yang tidak berbahaya. Bakteri Salmonella sp. pada cilok juga aman dikonsumsi karena tidak adanya bakteri pada saat diuji ke medium SSA.

\section{DAFTAR PUSTAKA}

Asteriani, Elmatris dan Endrinaldi. 2006. Analisis Kandungan Boraks dalam Mie Basah yang Beredar di Kota Makassar. Jurnal Chemica 11(1). Hal. 57-64.

Antara, Nyoman Semadi, Ida Bagus Djaya Utama Dauh, Ni Made Ita Seri Utami. 2008. Tingkat Cemaran Bakteri Coliform, Salmonella sp., dan Staphylococcus aureus Pada Daging Babi. Jurnal Agrotekno, Volume (14 (2): 51-55.

BPOM. 2002. Informasi Pengamanan Bahan Berbahaya: Boraks (Borax). Direktorat Pengawasan Produk dan Bahan Berbahaya, Deputi Bidang Pengawasan Keamanan Pangan dan Bahan Berbahaya. Jakarta

Bellittz HD, Grosch V, Chieberle P. 2009. Food Chemistry. Edisi 4.Berlin: Spinger.

Budiono, Hendra, Harlis, Retni, S. Budiarti. 2012. Analisis Ambang Batas Escherichia coli Sebagai Indikator Pencemaran Pada Daging Sapi di Rumah Pemotongan Hewan Kota Jambi. Jurnal Biospecies, 5 (1): $14-21$

Cahyadi, W. 2008. Analisis dan Aspek Kesehatan Bahan Tambahan Pangan. Edisi 2 Cetakan I. Bumi Aksara. Jakarta

Delost, MD. 2005. Introduction to Diagnostic Microbiology for The Laboratory Science. Jones and Bartlett Learning: Burlington. 54 : 212-213.
Devirian, TA and Volpe, SL. 2003. The Physiological Effect of Dietary Born. Crit. Rev. Food Sci and Nutr. 43(2) : 219-31.

EBA. 2010. European Borates Association Comments on Annex (Hazard Assess ment) of Annex XV Dossiers: Proposal For Identification of a Substance as a CMR Cat 1 or 2, vPvB or a Substance of ab Equivalent Level of Concern; Disodium Tetraborate, Ahydrous; Proposal forIdentification of a Substance as Substance of Very High Concern (SVHC) Boric Acid.European Borates Association A.I.S.B.L.

Herlich, K. 1990. Officials Methods of Analysis of The Association of Official Analytical Chemists. Edisi 15. Station Washington. DC. AOAC Inc.

Litovitz, T. L., W. K. Schwartz, G. M. Oderda and B. F. Schmitz. 1998. Clinical Manifertations of Toxicity in a Series of 784 Borac Acid Ingestion. American Journal Emergency Medical 6. 209-215

Sujaya, I Nengah. 2009. Pembinaan Pedagang Makanan Kaki Lima untuk Meningkatkan Higiene dan Sanitasi Pengolahan dan Penyediaan Makanan di desa Penatih. Denpasar Timur.

Janny .2009. Boric Acid and Borax in Food. (http://www.cfs. gov.hkenglishmultime diamultimedia pubmultimedia pub f sf 37 01. html). Diakses 11 November 2016.

Lee, D., 1989. Rhodamine B. (http:// www.osha.gov/dtssltc/methods/partial/ pv2072/pv2072.html). Diakses 11 November 2016.

Mansauda KLR, Fatimawati dan Kojong N. 2014. Analisis Cemaran Bakteri Coliform pada Saus Tomat Jajanan Bakso Tusuk yang Beredar di Manado. Jurnal Ilmiah Farmasi Universitas Sam Ratulangi. Vol 3 (2): 110. 
Matuwo. 2012. Mikrobiologi pada Daging Ayam.(http://repository.unhas.ac.id/ bitstream/handle/123456789/1479/ Skripsi.pdf). Diakses tanggal 11 November 2016.

Narumi, Hasutji Endah, Zuhriansyah, Imam Mustofa. 2009. Deteksi Pencemaran Bakteri Salmonella sp. Pada Udang Putih (Panaeus merguiensis) Segar Di Pasar Tradisional Kotamadya Surabaya. Jurnal Ilmiah Perikanan dan Kelautan,1 (1): 87-91.

Odonkor, Stephen T. dan Joseph K. Ampofo. 2013. Salmonella As An Indicator of Bacteriological Quality of Water: an Overview. Microbiology Research 2013, 4 (2): 05-11.

Purnomo H dan Rahadiyan D. 2008. Indonesian Traditional Meatball. International Food Research Journal.15 (2): 101-108.

Saparinto, C dan Hidayati, D. 2006. Bahan Tambahan Pangan. Penerbit: Kanisius, Yogyakarta.
See, AW et al. 2010. Risk and Health Effect of Boric Acid. American American Jurnal of Applied Sciences, 7 (5): 620-627.

SNI. 2004. Saus Tomat. Badan Standarisasi Nasional. Jakarta.

USDA. 2006. Human Health and Ecological Risk Assessment for Borax (Sporax $®)$ Final Report. Syracuse Environmental Research Associates Inc., Arlington.

Widyaningsih, T.D. dan Murtini, ES. 2006. Alternatif Pengganti Formalin Pada Produk Pangan. Trubus Agrisarana. Jakarta.

Winarno, F.G. dan Sulistiyowati. 1994. Bahan Tambahan Untuk Makanan dan Kontaminan. Pustaka Sinar Harapan, Jakarta.

Yuliarti, N. 2007. Awas Bahaya di Balik Lezatnya Makanan. Andi Offset. Yogyakarta. 